\title{
Evidence for optimal HIV testing intervals in HIV-negative individuals from various risk groups: a systematic review protocol
}

\author{
GP Traversy'1, T Austin'1, J Yau', K Timmerman ${ }^{1 *}$
}

\section{Abstract}

Background: Evidence-based recommendations for HIV testing are essential for health care providers. However, it is unclear whether there is sufficient evidence to support recommendations for HIV testing frequencies in a variety of HIV risk groups.

Objective: The aim of this document is to outline the methodological protocol of a systematic review that would gather evidence for the optimal frequency of HIV testing among individuals in various HIV risk groups with respect to personal and public health outcomes and cost-effectiveness.

Methods: This protocol adheres to the PRISMA-P reporting items, and the review is registered with PROSPERO. The target population includes individuals who may have undiagnosed HIV infection. Different frequencies of HIV testing will be compared and outcomes to do with personal and public health, patient values/preferences and costs will be examined. The search strategy will encompass searches in MEDLINE/Pubmed, Scopus, Embase, Cochrane, PsychINFO, and EconLit, as well as grey literature sources. Articles will be screened by title/ abstract, and subsequently by full-text, in duplicate. Extraction of pertinent data from the screened references will be carried out by one reviewer and verified by a second. Multiple critical appraisal tools will be used to assess individual study quality, and the GRADE approach will be used to appraise the overall quality of the evidence. Data will be synthesized narratively, and the results will be published in a peer-reviewed journal.

Discussion: This systematic review, designed with extensive input from content experts, will help to identify key evidence to inform recommendations for HIV testing frequency.

\section{Affiliation}

${ }^{1}$ Centre for Communicable Diseases and Infection Control, Public Health Agency of Canada, Ottawa, ON

\section{*Correspondence: karen.}

timmerman@phac-aspc.gc.ca

Suggested citation: Traversy GP, Austin T, Yau J, Timmerman K. Evidence for optimal HIV testing intervals in HIV-negative individuals from various risk groups: a systematic review protocol. Can Commun Dis Rep. 2017;43(2):38-48. https://doi.org/10.14745/ccdr.v43i02a02

\section{Background}

HIV testing is a key element of the HIV cascade of care, representing the first "90" of the Joint United Nations

Programme on HIV/AIDS (UNAIDS) 90-90-90 global strategy for addressing HIV/AIDS (1). HIV diagnosis is essential for linkage to care and initiation of antiretroviral therapy (ART), which may subsequently lead to decreased viral load, reduced infectivity and improved personal health outcomes $(2,3)$. Low rates of screening and testing are therefore a potential limiting factor for the success of HIV prevention strategies. Up to $50 \%$ of new HIV infections may be attributed to those who are unaware of their infection (4-7). In Canada, it is estimated that individuals who are unaware of their infection represent $21 \%$ of all those who are HIV-infected (8).

Certain populations who are at higher risk for HIV infection, such as men who have sex with men (MSM), injection drug users (IDU) or Indigenous peoples, may benefit from more frequent HIV testing. Accordingly, an important question in developing recommendations and strategies for HIV testing is how often should individuals from different risk groups be tested for HIV. Answering this question requires balancing the potential benefits of enhanced screening with the increased costs of the screening, as well as considerations of patient values and preferences.

Clear and specific guidance for how often to test individuals from different risk groups may help health care providers improve their testing behaviours and normalize this practice. A recent systematic review of guidelines found that a number of the guidelines recommend annual screening for groups including MSM and IDU but that others cite a paucity of data frequency of testing for HIV in certain groups, leading to some inconsistencies in guidance (9). At the federal level, the Public Health Agency of Canada's HIV Screening and Testing Guide states that individuals involved in high-risk practices should be screened for HIV at least annually but that there is insufficient evidence to provide recommendations for individual scenarios (10). 
Many of the guidelines reviewed in the systematic review of guidelines mentioned above are several years old. In addition, guideline developers do not always describe the basis for their recommendations (e.g. systematic review versus expert opinion). A thorough, up-to-date review of scientific evidence related to HIV testing frequency is warranted and will be useful for developing timely quality guidance in Canada and abroad. The purpose of this article is to describe the protocol for a systematic review aimed at answering a number of questions related to how often to test for HIV.

\section{Objective}

The objective of the systematic review is to examine the scientific evidence that supports different frequencies of HIV testing for individuals in various risk groups who may have undiagnosed HIV.

The over-arching research question is: What is the optimal frequency of testing for HIV in individuals from various HIV risk groups with respect to personal and public health outcomes and cost-effectiveness? The sub-questions relevant to this include:

- What is the most effective frequency or interval of testing for HIV in people who have unknown or previously confirmed negative serostatus, with respect to personal/public health outcomes?

- What are patients' values and preferences with respect to how often to test/re-test for HIV?

- What are the potential harms associated with different HIV testing frequencies?

- What is the most cost-effective frequency or interval of re-testing for HIV in people who have an unknown or a previously confirmed negative serostatus?

\section{Methods}

Prior to the development of this protocol, a scoping search was completed to help guide protocol development and identify any similar works. This scoping search included a review of the reference lists from key guidelines identified in a systematic review of HIV testing guidelines (9) as well as searches for the term "HIV testing" on the websites of the following organizations/registries: Cochrane, the National Institute for Health and Care Excellence (NICE), the Canadian Agency for Drugs and Technologies in Health (CADTH), the UK Department of Health (NHS), the International Resource for Infection Control (iNRIC) and the PROSPERO International Prospective Register of systematic reviews.

This systematic review protocol has been designed in alignment with the Preferred Reporting Items for Systematic Review and Meta-Analysis Protocols (PRISMA-P) (11). See Appendix 1 for a list of the PRISMA-P reporting items.

Drafts of the protocol were peer-reviewed by several experts in infectious disease guideline development from the Public Health Agency of Canada prior to registration of the review with the PROSPERO International Prospective Register of systematic reviews (http://www.crd.york.ac.uk/PROSPERO; registration number CRD42016046575) (12). In addition, a health economist was consulted.

\section{Search strategy}

A comprehensive search strategy was designed in consultation with a research librarian. The search strategy was also peer-reviewed by an external research librarian prior to execution of the search. The full search strategy can be found in Appendix 2.

The following databases will be searched:
- MEDLINE/PubMed
- Scopus
- Embase
- Cochrane Library
- PsyciNFO
- EconLit

The following sources of grey literature will be searched:

- Open Grey

- ClinicalTrials.gov

- All relevant sources from the CADTH Grey Matters checklist (13)

The search strategies that will be used for Open Grey and ClinicalTrials.gov can be found in Appendix 3.

The CADTH Grey Matters tool is a checklist used to guide online searches for grey literature. It includes national and international health technology assessment websites, drug and device regulatory agencies, clinical trial registries, health economics resources, Canadian health prevalence or incidence databases and drug formulary web sites (13). A total of 40 relevant websites from the checklist were identified by the research team (drug formulary, drug advisory and warning, and surveillance databases were not considered relevant to the research question, for example). Many of the websites in the checklist do not include an advanced search option, so the large majority will be searched using the term "HIV" to provide the widest range of potentially relevant results. Websites with advanced search functions will be searched with combinations of "HIV" and "testing" or "screening" or "test" or "screen."

Grey literature searches will be carried out by two members of the research team independently, and all articles deemed potentially relevant will be added to the results of the database searches for further screening.

\section{Data management}

All references will be uploaded into the DistillerSR, a secure, internet-based systematic review management software (Evidence Partners). This software platform will be used for screening eligible articles, data extraction and quality assessment.

\section{Eligibility criteria}

\section{Language}

Articles published in English or French will be considered for the review. 


\section{Study design}

Eligible study designs will vary depending on the specific research sub-question. For all search questions, other systematic reviews will not be explicitly excluded. Rather, the reference lists will be scanned for relevant articles that may have otherwise been missed.

Table 1 outlines the study designs that will be considered for each of the research sub-questions.

Table 1: Study designs eligible for inclusion in the review, by research sub-question

\begin{tabular}{|c|c|}
\hline Research sub-question & Eligible study designs \\
\hline $\begin{array}{l}\text { With respect to personal/public } \\
\text { health outcomes, what is the most } \\
\text { effective frequency or interval of re- } \\
\text { testing for HIV in people who have } \\
\text { unknown or previously confirmed } \\
\text { negative serostatus? }\end{array}$ & $\begin{array}{l}\text { Quantitative (particularly comparative) } \\
\text { studies: } \\
\text { - Randomized controlled trials (RCTs) } \\
\text { - } \quad \text { Non-randomized controlled trials } \\
\text { - } \quad \text { Longitudinal observational studies (e.g. } \\
\text { cohort/registry studies) } \\
\text { - Before/after designs (e.g. interrupted } \\
\text { time series) } \\
\text { - Retrospective studies } \\
\text { - Intervention studies } \\
\text { - } \quad \text { Cross-sectional studies } \\
\text { - Modelling studies }\end{array}$ \\
\hline $\begin{array}{l}\text { What are patients' values and } \\
\text { preferences with respect to how } \\
\text { often to test/re-test for HIV? }\end{array}$ & $\begin{array}{l}\text { Qualitative studies } \\
\text { Surveys }\end{array}$ \\
\hline $\begin{array}{l}\text { What are the potential harms } \\
\text { associated with different HIV } \\
\text { testing frequencies? }\end{array}$ & $\begin{array}{l}\text { Quantitative and qualitative studies will be } \\
\text { considered }\end{array}$ \\
\hline $\begin{array}{l}\text { What is the most cost-effective } \\
\text { frequency or interval of re-testing } \\
\text { for HIV in people who have an } \\
\text { unknown or a previously confirmed } \\
\text { negative serostatus? }\end{array}$ & $\begin{array}{l}\text { Costing studies: } \\
\text { - Cost-effectiveness studies, cost-benefit, } \\
\text { cost-consequence, cost-utility, cost } \\
\text { minimization } \\
\text { - Modelling studies }\end{array}$ \\
\hline
\end{tabular}

\section{Population}

The target population includes individuals who may have undiagnosed HIV infection.

\section{Intervention}

The intervention of interest is HIV screening/testing at varying intervals.

\section{Comparison}

The effects of the intervention will be compared to any the following:

- Other interventions

- "Normal" or "standard" state of care (as defined in a given study)

- Before/after comparisons

\section{Setting}

Studies will be considered if they are held in any setting where HIV testing could be conducted.

\section{Exclusion criteria}

Articles will also be excluded if they are:

- Published prior to 2000

- Commentaries, editorials, letters to the editor, conference abstracts, poster presentations

- Guidelines/ policy papers/ policy documents

\section{Outcomes}

Several potential outcomes that could be relevant for each of the research sub-questions have been identified. However, the possibility exists that not all of the outcomes will be represented in the literature, as some may not have been examined. The primary and secondary outcomes of interest for each research question are outlined in Table 2.

\section{Table 2: Potential outcomes for each of the research sub-questions}

\begin{tabular}{|c|c|}
\hline Research sub-question & Outcomes \\
\hline \multirow[t]{2}{*}{$\begin{array}{l}\text { With respect to personal/public } \\
\text { health outcomes, what is the } \\
\text { most effective frequency or } \\
\text { interval of re-testing for HIV in } \\
\text { people who have unknown or } \\
\text { previously confirmed negative } \\
\text { serostatus? }\end{array}$} & $\begin{array}{l}\text { Primary outcomes: } \\
\text { - Time between HIV exposure/infection } \\
\text { and diagnosis } \\
\text { - CD4 cell count and/or viral load at } \\
\text { diagnosis } \\
\text { - Number/percent of patients receiving } \\
\text { HIV tests } \\
\text { - Number of new HIV diagnoses among } \\
\text { varying groups } \\
\text { - Change in number/percent of individuals } \\
\text { with undiagnosed HIV infection } \\
\text { (modelling) }\end{array}$ \\
\hline & $\begin{array}{l}\text { Secondary outcomes: } \\
\text { - Number of patients successfully linked } \\
\text { to care } \\
\text { - Number of patients beginning ART } \\
\text { - Number of HIV infections averted } \\
\text { (modelling) }\end{array}$ \\
\hline $\begin{array}{l}\text { What are patients' values and } \\
\text { preferences with respect to how } \\
\text { often to test/re-test for HIV? }\end{array}$ & $\begin{array}{l}\text { - } \text { Patient level of comfort with testing } \\
\text { - Uptake of HIV testing } \\
\text { - Acceptability of a given testing frequency }\end{array}$ \\
\hline $\begin{array}{l}\text { What are the potential harms } \\
\text { associated with different HIV } \\
\text { testing frequencies? }\end{array}$ & $\begin{array}{l}\text { - Psychological distress or other } \\
\text { psychosocial harms } \\
\text { - Labelling } \\
\text { - Feelings of stigmatization } \\
\text { - False positives } \\
\text { - False negatives } \\
\text { Note: Studies of outcomes on psychosocial } \\
\text { or other harms related to true positives or } \\
\text { true negatives will not be included. }\end{array}$ \\
\hline $\begin{array}{l}\text { What is the most cost-effective } \\
\text { frequency or interval of } \\
\text { re-testing for HIV in people who } \\
\text { have an unknown or a previously } \\
\text { confirmed negative serostatus? }\end{array}$ & $\begin{array}{l}\text { - All outcomes from the pertinent study } \\
\text { types will be considered }\end{array}$ \\
\hline
\end{tabular}

\section{Screening/selection of articles}

All references identified in the search will be screened based on title and abstract following removal of duplicates. The eligibility criteria above will be used to determine inclusion and exclusion 
of articles at the title/abstract-screening stage. Screening of titles and abstracts will be performed in duplicate by two reviewers.

Disagreements will be reconciled through discussion with a third reviewer.

Full-text screening will be performed on titles with abstracts that meet the above criteria or for cases in which it is unclear whether this is the case. At the full-text screening stage, the eligibility criteria, as well as the outcomes listed above, will guide exclusion of irrelevant articles. Full-text screening will be performed in duplicate by two reviewers. Disagreements will be reconciled through discussion with a third reviewer.

Reasons for exclusion will be recorded at each step of the screening process. The results of the screening will be presented in a flowchart consistent with PRISMA recommendations (14).

\section{Data extraction}

Extraction of pertinent data from the screened references will be carried out by one reviewer and verified by another in order to reduce bias or errors in extraction. Any disagreements will be resolved through discussion with one or two other reviewers. Study authors may be contacted if there are any major uncertainties. All pertinent data (i.e. year of publication, period of data collection, study population, sample size, location, study setting, study design, intervention, comparison, results/ outcomes, quality assessment score, etc.) will be extracted into evidence tables.

Duplicate, overlapping or companion studies, if identified during the screening process, will be dealt with by extracting the data into a single collection form or by extracting the data separately and combining these into a single input afterwards, as per the Cochrane Handbook for Systematic Reviews of Interventions (15).

\section{Quality assessment}

Quality assessment will be carried out for individual studies included in the review, as well as for the overall body of evidence. Different methods of assessment will be used as appropriate for the study type.

The following assessment tools will be used for individual studies:

- Cochrane risk of bias for RCTs (15)

- Effective Public Health Practice Project (EPHPP) Quality Assessment Tool for other quantitative studies (16-18)

- Critical Appraisal Skills Programme (CASP) Qualitative Checklist for qualitative studies (19)

For the overall body of evidence, the quality of evidence will be assessed using the GRADE approach (15).

\section{Data synthesis}

Data will be synthesized narratively. If there is sufficient homogeneity among the evidence, a meta-analysis may be considered, although this is unlikely due to the variety of evidence sources being sought.

\section{Subgroup analysis}

The initial search will not target any specific subgroups. If evidence emerges for specific subgroups (e.g. MSM, IDU, Indigenous peoples, etc.) then the results will be disaggregated and reported narratively in separate sections for each subgroup.

\section{Assessment of meta-biases}

Statistical assessment of meta-biases such as publication bias across studies (e.g. Egger's test) will likely not be possible given the wide variety of evidence being sought and the likelihood of inclusion of a large proportion of studies with observational designs (20). The potential for publication bias will however be reduced by employing a rigorous search of grey literature, and the potential for substantial publication bias in observational studies will be taken into account when assessing the overall body of evidence using the GRADE approach (20). Selective outcome reporting will be assessed in RCTs by comparing the reported results of studies with the outcomes reported in the methods section of the protocol of the study. This will factor into quality assessment with the Cochrane risk of bias tool (15).

\section{Amendments}

The research team does not foresee any amendments to the protocol prior to carrying out the systematic review. However, if this is necessary, all amendments will be recorded as they occur and reflected in the PROSPERO record for this review. Amendments will also be documented in the final publication.

\section{Dissemination}

A manuscript of the results of the systematic review will be prepared and submitted for publication in a peer-reviewed journal. The results will be presented according to the Preferred Reporting Items for Systematic Reviews and Meta-Analyses (PRISMA) guidelines (14).

\section{Discussion}

To the best of our knowledge, this will be the first published systematic review examining evidence supporting recommendations for HIV testing frequency. The evidence identified in this review may be useful to update or create new guidance around HIV testing in Canada; groups outside Canada may also find it useful. The development of specific, evidence-based recommendations will help health care providers streamline and improve their HIV testing practices. Such recommendations can also be used by the public to manage their own sexual health.

Enhanced HIV screening and testing will help decrease the substantial portion of individuals with HIV who are unaware of their infection. This group contributes to a substantial proportion of new HIV infections, and evidence suggests that once these individuals are aware of their infection, they will be more likely to take steps to minimize the likelihood of transmission $(4,21)$. HIV diagnosis is also the first step toward obtaining treatment, and thus, enhanced screening and testing yields benefits for personal and public health. 
The strengths of this systematic review protocol include extensive input from content experts in the development of HIV and sexually transmitted infection guidelines and health economics. Another strength is the external peer review of the research librarian-designed search strategy.

One limitation of the review could be the potential inclusion of predominantly observational studies, given the difficulty of carrying out experimental studies on the topic. This may raise concerns regarding the quality of evidence; however, the results of the quality assessments will be published, and thus assessment of bias in the evidence will be transparent.

If this systematic review fails to find evidence to answer one or more of the research questions, this will be documented in the results. A "negative" finding will still be of use to guideline developers as it provides validity to those guidelines that cite a lack of evidence for HIV-testing interval recommendations (9) and suggests that such recommendations may need to be made on a jurisdiction-by-jurisdiction basis, based on expert opinion. It would also help highlight gaps in evidence, which could be useful for guiding future research.

\section{Acknowledgements}

We would like to thank Michèle Sabourin, Kelsey Young, Lisa Pogany, Rachel Bennett, Ulrick Auguste, Cathy Latham-Carmanico, Bakhtiar Anwar, Jun Wu and Margaret Gale-Rowe for their constructive review and feedback on the draft protocol. We would also like to thank the research librarians, Connie Barrowclough and Katherine Merucci, who helped design and carry out our systematic search, and Margaret Sampson for peer-reviewing the search strategy.

\section{Authors' contributions}

KT is the guarantor. GT drafted the protocol for the review, and all authors made substantial contributions to refine the research question/sub-questions, the study eligibility and exclusion criteria, the outcomes of interest, the screening, extraction and quality assessment processes, and the search strategy (with the help of a trained research librarian). GT, TA and JY will draft the manuscript. All authors will read, provide feedback and approve the final manuscript.

\section{Conflict of interest}

None.

\section{Funding}

This study was supported by the Public Health Agency of Canada. The authors have no sources of external funding to declare.

\section{References}

1. Joint United Nations Programme on HIV/AIDS. 90-90-90: An ambitious treatment target to help end the AIDS epidemic. Geneva: UNAIDS; 2014.

2. INSIGHT START Study Group, Lundgren JD, Babiker AG, Gordin F, Emery S, Grund B, Sharma S, Avihingsanon A, Cooper DA, Fätkenheuer G, Llibre JM, Molina JM, Munderi P, Schechter M, Wood R, Klingman KL, Collins S, Lane HC, Phillips AN, Neaton JD. Initiation of antiretroviral therapy in early asymptomatic HIV infection. N Engl J Med. 2015 Aug 27;373(9):795-807.

3. Cohen MS, Chen YQ, McCauley M, Gamble T, Hosseinipour MC, Kumarasamy N, Hakim JG, Kumwenda J, Grinsztejn B, Pilotto JH, Godbole SV, Mehendale S, Chariyalertsak S, Santos BR, Mayer KH, Hoffman IF, Eshleman SH, PiwowarManning E, Wang L, Makhema J, Mills LA, de Bruyn G, Sanne I, Eron J, Gallant J, Havlir D, Swindells S, Ribaudo H, Elharrar V, Burns D, Taha TE, Nielsen-Saines K, Celentano D, Essex M, Fleming TR; HPTN 052 Study Team. Prevention of HIV-1 Infection with early antiretroviral therapy. N Engl J Med. 2011;365(6):493-505.

4. Marks G, Crepaz N, Janssen RS. Estimating sexual transmission of HIV from persons aware and unaware that they are infected with the virus in the USA. AIDS. 2006;20(10):1447-50.

5. McNairy ML, El-Sadr WM. Antiretroviral therapy for the prevention of HIV transmission: what will it take? Clin Infect Dis. 2014;58(7):1003-11.

6. McNairy ML, Cohen M, El-Sadr WM. Antiretroviral therapy for prevention is a combination strategy. Curr HIV/AIDS Rep. 2013;10(2):152-8.

7. Skarbinski J, Rosenberg E, Paz-Bailey G, Hall HI, Rose CE, Viall $\mathrm{AH}$, et al. Human immunodeficiency virus transmission at each step of the care continuum in the United States. JAMA Intern Med. 2015;175(4):588-96.

8. Tomas K, Dhami P, Houston C, Ogunnaike-Cooke S, Rank C. HIV in Canada: 2009 to 2014. Can Comm Dis Rep. 2015;41(12):292-304. Available from: http://www.phac-aspc. gc.ca/publicat/ccdr-rmtc/15vol41/dr-rm41-12/ar-01-eng.php.

9. Austin T, Traversy GP, Ha S, Timmerman K. Canadian and international recommendations on the frequency of HIV screening and testing: a systematic review. Can Comm Dis Rep. 2016;42:161-8. Available from: http://www.phac-aspc. gc.ca/publicat/ccdr-rmtc/16vol42/dr-rm42-8/ar-03-eng.php.

10. Public Health Agency of Canada. Human immunodeficiency virus: HIV screening and testing guide [Internet]. 2012 (modified 2014 Aug 5; cited 2016 Nov 21). Available from: http://www.phac-aspc.gc.ca/aids-sida/guide/hivstg-vihgddeng.php.

11. Shamseer L, Moher D, Clarke M, Ghersi D, Liberati A, Petticrew M, Shekelle P, Stewart LA; PRISMA-P Group.. Preferred reporting items for systematic review and metaanalysis protocols (PRISMA-P) 2015: elaboration and explanation. BMJ. 2015;349:g7647. doi: 10.1136/bmj.g7647.

12. University of York Centre for Reviews and Dissemination. Guidance notes for registering a systematic review protocol with PROSPERO [Internet]. Toronto (ON): Univeristy of York: 


\section{SYSTEMATIC REVIEW}

2016 May (cited 2016 Nov 21). Available from: http://www. crd.york.ac.uk/PROSPERO/documents/Registering\%20a\%20 review\%20on\%20PROSPERO.pdf.

13. Canadian Agency for Drugs and Technologies in Health. Grey Matters: a practical tool for searching health-related grey literature [Internet]. Ottawa (ON): CADTH; 2015 Dec (cited 2016 Oct). Available from: https://www.cadth.ca/ resources/finding-evidence/grey-matters

14. Liberati A, Altman DG, Tetzlaff J, Mulrow C, Gotzsche PC, loannidis JP, Clarke M, Devereaux PJ, Kleijnen J, Moher D. The PRISMA statement for reporting systematic reviews and meta-analyses of studies that evaluate healthcare interventions: explanation and elaboration. BMJ. 2009;339:b2700. doi: 10.1136/bmj.b2700.

15. Higgins JPT, Green S, editors. Cochrane handbook for systematic reviews of interventions. Version 5.1.0. London (UK): The Cochrane Collaboration; 2011.

16. Armijo-Olivo S, Stiles CR, Hagen NA, Biondo PD, Cummings GG. Assessment of study quality for systematic reviews: a comparison of the Cochrane Collaboration Risk of Bias Tool and the Effective Public Health Practice Project Quality Assessment tool: methodological research. J Eval Clin Pract. 2012;18(1):12-8.
17. Thomas BH, Ciliska D, Dobbins M, Micucci S. A process for systematically reviewing the literature: providing the research evidence for public health nursing interventions. Worldviews Evid Based Nurs. 2004;1(3):176-84.

18. Deeks JJ, Dinnes J, D'Amico R, Sowden AJ, Sakarovitch C, Song F, Petticrew M, Altman DG. Evaluating nonrandomised intervention studies. Health Technol Assess. $2003 ; 7(27): 1-173$.

19. Hannes K. Chapter 4: Critical appraisal of qualitative research. In: Noyes J, Booth A, Hannes K, Harden A, Harris J, Lewin S, Lockwood C, editors. Supplementary guidance for inclusion of qualitative research in Cochrane Systematic Reviews of Interventions: Cochrane Collaboration Qualitative Methods Group; 2011.

20. Guyatt GH, Oxman AD, Montori V, Vist G, Kunz R, Brozek J, Alonso-Coello P, Djulbegovic B, Atkins D, Falck-Ytter Y, Williams JW Jr, Meerpohl J, Norris SL, Akl EA, Schünemann HJ. GRADE guidelines: 5. Rating the quality of evidence publication bias. J Clin Epidemiol. 2011:12;64(12):1277-82.

21. Marks G, Crepaz N, Senterfitt JW, Janssen RS. Meta-analysis of high-risk sexual behavior in persons aware and unaware they are infected with HIV in the United States: implications for HIV prevention programs. J Acquir Immune Defic Syndr. 2005;39(4):446-53. 


\section{Appendix 1: Completed PRISMA-P checklist for the systematic review}

\begin{tabular}{|c|c|c|c|}
\hline Section and topic & Item & Checklist item & Line no(s). \\
\hline \multicolumn{4}{|l|}{ ADMINISTRATIVE INFORMATION } \\
\hline \multicolumn{4}{|l|}{ Title: } \\
\hline Identification & $1 \mathrm{a}$ & Identify the report as a protocol of a systematic review & 1,67 \\
\hline Update & $1 \mathrm{~b}$ & If the protocol is for an update of a previous systematic review, identify as such & N/A \\
\hline Registration & 2 & $\begin{array}{l}\text { If registered, provide the name of the registry (such as PROSPERO) and } \\
\text { registration number }\end{array}$ & 103 \\
\hline \multicolumn{4}{|l|}{ Authors: } \\
\hline Contact & $3 a$ & $\begin{array}{l}\text { Provide name, institutional affiliation, email address of all protocol authors; } \\
\text { provide physical mailing address of corresponding author }\end{array}$ & $4-7$ \\
\hline Contributions & $3 b$ & $\begin{array}{l}\text { Describe contributions of protocol authors and identify the guarantor of the } \\
\text { review }\end{array}$ & $262-267$ \\
\hline Amendments & 4 & $\begin{array}{l}\text { If the protocol represents an amendment of a previously completed or published } \\
\text { protocol, identify as such and list changes; otherwise, state plan for documenting } \\
\text { important protocol amendments }\end{array}$ & $220-224$ \\
\hline \multicolumn{4}{|c|}{ ( } \\
\hline Sources & $5 a$ & Indicate sources of financial or other support for the review & $270-273$ \\
\hline Sponsor & $5 b$ & Provide name for the review funder and/or sponsor & $270-273$ \\
\hline Role of sponsor or funder & $5 c$ & $\begin{array}{l}\text { Describe roles of funder(s), sponsor(s) and/or institution(s), if any, in developing } \\
\text { the protocol }\end{array}$ & N/A \\
\hline \multicolumn{4}{|l|}{ INTRODUCTION } \\
\hline Rationale & 6 & Describe the rationale for the review in the context of what is already known & $52-68$ \\
\hline Objectives & 7 & $\begin{array}{l}\text { Provide an explicit statement of the question(s) the review will address with } \\
\text { reference to participants, interventions, comparators, and outcomes (PICO) }\end{array}$ & $151-174$ \\
\hline \multicolumn{4}{|l|}{ METHODS } \\
\hline Eligibility criteria & 8 & $\begin{array}{l}\text { Specify the study characteristics (such as PICO, study design, setting, time frame) } \\
\text { and report characteristics (such as years considered, language, publication } \\
\text { status) to be used as criteria for eligibility for the review }\end{array}$ & $140-174$ \\
\hline Information sources & 9 & $\begin{array}{l}\text { Describe all intended information sources (such as electronic databases, contact } \\
\text { with study authors, trial registers or other grey literature sources) with planned } \\
\text { dates of coverage }\end{array}$ & $\begin{array}{r}109-129 \\
145,191-192\end{array}$ \\
\hline Search strategy & 10 & $\begin{array}{l}\text { Present draft of search strategy to be used for at least one electronic database, } \\
\text { including planned limits, so that it could be repeated }\end{array}$ & 344 \\
\hline \multicolumn{4}{|l|}{ Study records: } \\
\hline Data management & $11 a$ & $\begin{array}{l}\text { Describe the mechanism(s) that will be used to manage records and data } \\
\text { throughout the review }\end{array}$ & 137 \\
\hline Selection process & $11 b$ & $\begin{array}{l}\text { State the process that will be used for selecting studies (such as two } \\
\text { independent reviewers) through each phase of the review (that is, screening, } \\
\text { eligibility and inclusion in meta-analysis) }\end{array}$ & $175-187$ \\
\hline Data collection process & $11 c$ & $\begin{array}{l}\text { Describe planned method of extracting data from reports (such as piloting } \\
\text { forms, done independently, in duplicate), any processes for obtaining and } \\
\text { confirming data from investigators }\end{array}$ & 188-199 \\
\hline Data items & 12 & $\begin{array}{l}\text { List and define all variables for which data will be sought (such as PICO items, } \\
\text { funding sources), any pre-planned data assumptions and simplifications }\end{array}$ & $192-194$ \\
\hline Outcomes and prioritization & 13 & $\begin{array}{l}\text { List and define all outcomes for which data will be sought, including prioritization } \\
\text { of main and additional outcomes, with rationale }\end{array}$ & 173 \\
\hline Risk of bias in individual studies & 14 & $\begin{array}{l}\text { Describe anticipated methods for assessing risk of bias of individual studies, } \\
\text { including whether this will be done at the outcome or study level, or both; state } \\
\text { how this information will be used in data synthesis }\end{array}$ & $200-209$ \\
\hline \multirow[t]{4}{*}{ Data synthesis } & $15 a$ & Describe criteria under which study data will be quantitatively synthesized & 213 \\
\hline & $15 b$ & $\begin{array}{l}\text { If data are appropriate for quantitative synthesis, describe planned summary measures, } \\
\text { methods of handling data and methods of combining data from studies, including any } \\
\text { planned exploration of consistency (such as } \mathrm{I}^{2}, \text { Kendall's } \mathrm{T} \text { ) }\end{array}$ & N/A \\
\hline & $15 c$ & $\begin{array}{l}\text { Describe any proposed additional analyses (such as sensitivity or subgroup analyses, } \\
\text { meta-regression) }\end{array}$ & $216-219$ \\
\hline & $15 d$ & If quantitative synthesis is not appropriate, describe the type of summary planned & $212-219$ \\
\hline Meta-bias(es) & 16 & $\begin{array}{l}\text { Specify any planned assessment of meta-bias(es) (such as publication bias across } \\
\text { studies, selective reporting within studies) }\end{array}$ & $220-229$ \\
\hline Confidence in cumulative evidence & 17 & Describe how the strength of the body of evidence will be assessed (such as GRADE) & $210-211$ \\
\hline
\end{tabular}

Abbreviation: Line no(s), Line numbers 


\section{Appendix 2: Search Strategy}

All searches run and downloaded on September 16, 2016.

\section{Database(s): Econlit 1886 to August 2016}

\section{Search Strategy:}

\begin{tabular}{|c|c|c|}
\hline No. & Searches & Results \\
\hline 1 & $\begin{array}{l}\text { (hiv or hiv+ or hiv-1 or hiv-2 or hiv1 or hiv2 or } \\
\text { hivaids or (human immun* adj2 virus) or virus de } \\
\text { l'immunodeficience humaine or vih or vih+ or vih1 or } \\
\text { vih2 or vih-1 or vih-2).af. }\end{array}$ & 1713 \\
\hline 2 & $\begin{array}{l}\text { (screen* or rescreen* or test or tests or testing or } \\
\text { tested or retest* or depistage or "diagnostic du } \\
\text { VIH").af. }\end{array}$ & 91581 \\
\hline 3 & (freque* or interval*).af. & 26404 \\
\hline 4 & 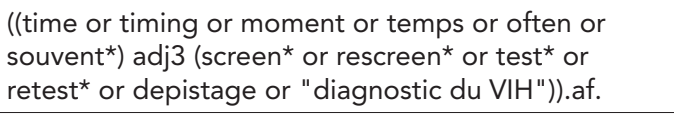 & 1484 \\
\hline 5 & 1 and 2 and 3 & 5 \\
\hline 6 & 1 and 4 & 2 \\
\hline 7 & or/5-6 & 7 \\
\hline 8 & limit 7 to $y r=$ "2000 -Current" & 6 \\
\hline
\end{tabular}

Abbreviation: No., Number
Database(s): PsycINFO 1806 to July Week 42016

\section{Search Strategy:}

\begin{tabular}{|c|c|c|}
\hline No. & Searches & Results \\
\hline 1 & exp hiv/ & 36417 \\
\hline 2 & $\begin{array}{l}\text { (hiv or hiv+ or hiv-1 or hiv- } 2 \text { or hiv1 or hiv2 or } \\
\text { hivaids or (human immun* adj2 virus) or virus de } \\
\text { l'immunodeficience humaine or vih or vih+ or vih1 or } \\
\text { vih2 or vih-1 or vih-2).ti. }\end{array}$ & 27738 \\
\hline 3 & $\begin{array}{l}\text { (hiv or hiv+ or hiv-1 or hiv-2 or hiv1 or hiv2 or } \\
\text { hivaids or (human immun* adj2 virus) or virus de } \\
\text { l'immunodeficience humaine or vih or vih+ or vih1 or } \\
\text { vih2 or vih-1 or vih-2).ab. /freq }=2\end{array}$ & 31713 \\
\hline 4 & or/1-3 & 41632 \\
\hline 5 & screening/ & 8117 \\
\hline 6 & screening tests/ & 5000 \\
\hline 7 & health screening/ & 2451 \\
\hline 8 & $\begin{array}{l}\text { (screen* or rescreen* or test or tests or testing or } \\
\text { tested or retest* or depistage or "diagnostic du VIH"). } \\
\text { ti. }\end{array}$ & 102858 \\
\hline 9 & $\begin{array}{l}\text { (screen* or rescreen* or test or tests or testing or } \\
\text { tested or retest* or depistage or "diagnostic du VIH"). } \\
\text { ab. /freq }=2\end{array}$ & 258239 \\
\hline 10 & or/5-9 & 304851 \\
\hline 11 & hiv test/ & 1880 \\
\hline 12 & (freque* or interval*).ti. & 22666 \\
\hline 13 & (freque* $^{\star}$ or interval*).ab. /freq $=2$ & 91053 \\
\hline 14 & or/12-13 & 100641 \\
\hline 15 & $\begin{array}{l}\text { ((time or timing or moment or temps or often or } \\
\text { souvent*) adj3 (screen* or rescreen* or test* or retest* } \\
\text { or depistage or "diagnostic du VIH")).ti. }\end{array}$ & 575 \\
\hline 16 & $\begin{array}{l}\text { ((time or timing or moment or temps or often or } \\
\left.\text { souvent }^{\star}\right) \text { adj3 (screen* or rescreen* or test* or retest* } \\
\text { or depistage or "diagnostic du VIH")).ab. /freq }=2\end{array}$ & 918 \\
\hline 17 & or/15-16 & 1366 \\
\hline 18 & (10 and 14$)$ or 17 & 10859 \\
\hline 19 & 4 and 18 & 197 \\
\hline 20 & 11 and (14 or 17) & 69 \\
\hline 21 & or/19-20 & 200 \\
\hline 22 & Dissertation Abstract.pt. & 413976 \\
\hline 23 & animals/ & 6443 \\
\hline 24 & case report/ or case report.tw. & 36249 \\
\hline 25 & or/22-24 & 456006 \\
\hline 26 & 21 not 25 & 176 \\
\hline 27 & limit 26 to $y r=$ "2000 -Current" & 164 \\
\hline
\end{tabular}


Database(s): Epub Ahead of Print, In-Process \& Other Non-Indexed Citations, Ovid MEDLINE(R) Daily and Ovid MEDLINE(R) 1946 to Present (20151216.up)

\section{Search Strategy:}

\begin{tabular}{|c|c|c|}
\hline No. & Searches & Results \\
\hline 1 & $\begin{array}{l}\text { (hiv or hiv }+ \text { or hiv-1 or hiv-2 or hiv1 or hiv2 or } \\
\text { hivaids or (human immun* adj2 virus) or virus de } \\
\text { l'immunodeficience humaine or vih or vih+ or } \\
\text { vih1 or vih2 or vih-1 or vih-2).ti,kf. }\end{array}$ & 204027 \\
\hline 2 & $\begin{array}{l}\text { (hiv or hiv }+ \text { or hiv-1 or hiv-2 or hiv1 or hiv2 or } \\
\text { hivaids or (human immun* adj2 virus) or virus de } \\
\text { l'immunodeficience humaine or vih or vih }+ \text { or } \\
\text { vih1 or vih2 or vih-1 or vih-2).ab. / freq=2 }\end{array}$ & 178603 \\
\hline 3 & exp HIV Infections/ & 252533 \\
\hline 4 & $\exp \mathrm{HIV} /$ & 89772 \\
\hline 5 & HIV Antibodies/ & 10284 \\
\hline 6 & or/1-5 & 326372 \\
\hline 7 & mass screening/ & 90016 \\
\hline 8 & Serologic Tests/ & 18348 \\
\hline 9 & $\begin{array}{l}\text { (screen* or rescreen* or test or tests or testing } \\
\text { or tested or retest* or depistage or "diagnostic } \\
\text { du VIH").ti,kf. }\end{array}$ & 470662 \\
\hline 10 & $\begin{array}{l}\text { (screen* or rescreen* or test or tests or testing } \\
\text { or tested or retest* or depistage or "diagnostic } \\
\left.\text { du } V \mid H^{\prime \prime}\right) . a b . / \text { freq }=2\end{array}$ & 935790 \\
\hline 11 & or/7-10 & 1246845 \\
\hline 12 & AIDS serodiagnosis/ & 6381 \\
\hline 13 & (freque* or interval*).ti,kf. & 132544 \\
\hline 14 & (freque ${ }^{\star}$ or interval*).ab. /freq $=2$ & 521701 \\
\hline 15 & or/13-14 & 594802 \\
\hline 16 & $\begin{array}{l}\text { ((time or timing or moment or temps or often or } \\
\text { souvent*) adj3 (screen* or rescreen* or test or } \\
\text { tests or testing or tested or retest* or depistage } \\
\text { or "diagnostic du VIH")).ti,kf. }\end{array}$ & 2150 \\
\hline 17 & 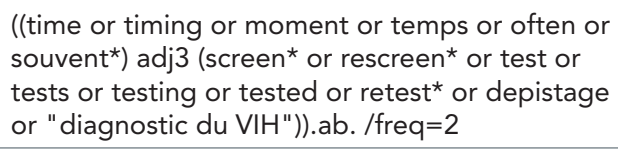 & 2569 \\
\hline 18 & or/16-17 & 4359 \\
\hline 19 & (11 and 15$)$ or 18 & 54568 \\
\hline 20 & 6 and 19 & 1580 \\
\hline 21 & 12 and (15 or 18$)$ & 157 \\
\hline 22 & 20 or 21 & 1610 \\
\hline 23 & (letter or editorial).pt. & 1360656 \\
\hline 24 & animal/ & 5981714 \\
\hline 25 & human/ & 16333570 \\
\hline 26 & 24 not (24 and 25 ) & 4284662 \\
\hline 27 & case reports/ or case report.tw. & 1885376 \\
\hline 28 & or/23,26-27 & 7265507 \\
\hline 29 & 22 not 28 & 1567 \\
\hline 30 & limit 29 to yr="2000 -Current" & 1171 \\
\hline
\end{tabular}

Abbreviation: No., Number
Scopus : Run September 16, 2016

TITLE ( "hiv" OR "hiv1" OR "hiv2 " OR "hivaids" OR "human immune deficiency virus" OR "human immunodeficiency virus" OR "virus de l'immunodeficience humaine" OR "vih" OR "vih1" OR "vih2" )

AND ( ( TITLE ( ( time OR timing OR moment OR temps OR often OR souvent*) W/3 ( screen* OR rescreen* OR test OR tests OR tested OR testing OR retest* OR "diagnostic du VIH" OR depistage ) ) ) OR ( ( TITLE-ABS ( screen* OR rescreen* OR test OR tests OR tested OR testing OR retest* OR "diagnostic du VIH" OR depistage ))

AND ( TITLE-ABS ( freque* OR interval* ) )) )

AND ( PUBYEAR > 1999)

AND SUBJAREA ( mult OR arts OR busi OR deci OR econ OR psyc OR soci )

\section{9 records}




\section{SYSTEMATIC REVIEW}

\section{Database(s): Embase 1974 to 2016 September 15}

\section{Search Strategy:}

\begin{tabular}{|c|c|c|}
\hline No. & Searches & Results \\
\hline 1 & $\begin{array}{l}\text { (hiv or hiv }+ \text { or hiv-1 or hiv-2 or hiv1 or hiv2 or } \\
\text { hivaids or (human immun* adj2 virus) or virus de } \\
\text { l'immunodeficience humaine or vih or vih+ or vih1 or vih2 } \\
\text { or vih-1 or vih-2).ti,kw. }\end{array}$ & 246105 \\
\hline 2 & $\begin{array}{l}\text { (hiv or hiv }+ \text { or hiv-1 or hiv- } 2 \text { or hiv1 or hiv2 or } \\
\text { hivaids or (human immun* adj2 virus) or virus de } \\
\text { l'immunodeficience humaine or vih or vih+ or vih1 or vih2 } \\
\text { or vih-1 or vih-2).ab. /freq }=2\end{array}$ & 204295 \\
\hline 3 & exp Human immunodeficiency virus infection/ & 328710 \\
\hline 4 & exp Human immunodeficiency virus/ & 160405 \\
\hline 5 & Human immunodeficiency virus antigen/ & 1810 \\
\hline 6 & Human immunodeficiency virus antibody/ & 8917 \\
\hline 7 & Human immunodeficiency virus infected patient/ & 26547 \\
\hline 8 & or/1-7 & 435387 \\
\hline 9 & mass screening/ & 52549 \\
\hline 10 & screening/ & 149792 \\
\hline 11 & screening test/ & 55924 \\
\hline 12 & rescreening/ & 227 \\
\hline 13 & serodiagnosis/ & 42942 \\
\hline 14 & $\begin{array}{l}\text { (screen* or rescreen* or test or tests or testing or tested } \\
\text { or retest* or depistage or "diagnostic du VIH").ti,kw. }\end{array}$ & 608987 \\
\hline 15 & $\begin{array}{l}\text { (screen* or rescreen* or test or tests or testing or tested } \\
\text { or retest* or depistage or "diagnostic du VIH").ab. / } \\
\text { freq }=2\end{array}$ & 1265723 \\
\hline 16 & or/9-15 & 1709594 \\
\hline 17 & exp hiv test/ & 6818 \\
\hline 18 & $\left(\right.$ freque ${ }^{\star}$ or interval*).ti,kw. & 162041 \\
\hline 19 & $\left(\right.$ freque $^{\star}$ or interval $\left.{ }^{\star}\right) \cdot a b . /$ freq $=2$ & 651528 \\
\hline 20 & or/18-19 & 739551 \\
\hline 21 & $\begin{array}{l}\text { ((time or timing or moment or temps or often or } \\
\left.\text { souvent }{ }^{\star}\right) \text { adj3 }(\text { screen* or rescreen* or test or tests or } \\
\text { testing or tested or retest }{ }^{\star} \text { or depistage or "diagnostic } \\
\text { du VIH")).ti,kw. }\end{array}$ & 2617 \\
\hline 22 & $\begin{array}{l}\text { ((time or timing or moment or temps or often or } \\
\left.\text { souvent }{ }^{\star}\right) \text { adj3 }(\text { screen* or rescreen* or test or tests or } \\
\text { testing or tested or retest* or depistage or "diagnostic } \\
\text { du VIH")).ab. /freq }=2\end{array}$ & 3598 \\
\hline 23 & or/21-22 & 5775 \\
\hline 24 & (16 and 20$)$ or 23 & 81929 \\
\hline 25 & 8 and 24 & 2539 \\
\hline 26 & 17 and (20 or 23$)$ & 316 \\
\hline 27 & or $/ 25-26$ & 2607 \\
\hline 28 & (letter or editorial).pt. & 1480511 \\
\hline 29 & animal/ & 1803158 \\
\hline 30 & human/ & 17470047 \\
\hline 31 & 29 not (29 and 30$)$ & 1350042 \\
\hline 32 & case study/ or case report.tw. & 362306 \\
\hline 33 & or $/ 28,31-32$ & 3168665 \\
\hline 34 & 27 not 33 & 2557 \\
\hline 35 & limit 34 to $y r=" 2000$-Current" & 2174 \\
\hline
\end{tabular}

\section{Cochrane}

Date Run: 16/09/16 19:05:13.171

Description:

\begin{tabular}{|c|c|c|}
\hline ID & Search & Hits \\
\hline$\# 1$ & [mh "HIV Infections"] or [mh HIV] & 9272 \\
\hline \#2 & [mh ^ "HIV Antibodies"] & 238 \\
\hline \#3 & $\begin{array}{l}\text { (hiv or hiv-1 or hiv-2 or hiv1 or hiv2 or hivaids } \\
\text { or human immune deficiency virus or human } \\
\text { immunodeficiency virus or human immuno-deficiency } \\
\text { virus or human immune-deficiency virus or virus de } \\
\text { l'immunodeficience humaine or vih or vih1 or vih2 or } \\
\text { vih-1 or vih-2):ti }\end{array}$ & 9923 \\
\hline \#4 & $\# 1$ or \#2 or \#3 & 12575 \\
\hline \#5 & {$\left[\mathrm{mh}^{\wedge} \wedge\right.$ "mass screening"] or [mh $\wedge$ "serologic tests"] } & 4877 \\
\hline \#6 & $\begin{array}{l}\text { (screen* or rescreen* or test or tests or tested or } \\
\text { testing or retest* or depistage or "diagnostic du } \\
\text { VIH"):ti }\end{array}$ & 21763 \\
\hline$\# 7$ & $\# 5$ or \#6 & 22979 \\
\hline \#8 & (freque* or interval*):ti & 6568 \\
\hline \#9 & $\begin{array}{l}\text { ((time or timing or moment or temps or souvent*) } \\
\text { near/3 (screen* or rescreen* or test or tests or } \\
\text { tested or testing or retest* or "diagnostic du } \mathrm{VIH}^{*} \text { or } \\
\text { depistage)):ti }\end{array}$ & 147 \\
\hline$\# 10$ & \#8 or \#9 & 6710 \\
\hline$\# 11$ & [mh ${ }^{\wedge}$ "AIDS serodiagnosis"] & 143 \\
\hline$\# 12$ & (\#7 and \#8) or \#9 & 332 \\
\hline$\# 13$ & $\# 10$ and \#11 & 3 \\
\hline \#14 & \#4 and \#12 & 17 \\
\hline \#15 & \#13 or \#14 Publication Year from 2000 to 2016 & 3 \\
\hline
\end{tabular}

Abbreviation: ID, Identification number 


\section{Appendix 3: Grey Literature Searches}

All grey literature searches run on October 27, 2016.

\section{Open Grey}

("HIV" OR "HIV+" or "HIV-1" OR "HIV-2" OR "HIV1" OR "HIV2" OR "HIVAIDS" OR ("human immun*" NEAR/2 "virus") OR

"human immunodeficiency virus" OR "human immunodeficiency virus infection") AND ("screening" OR "test*" OR "retest*" OR "rescreen*" OR "re-test*" OR "re-screen*")

Results: 163 items returned

Link to results:

http://www.opengrey.eu/search/request?q $=\% 28 \% 22 \mathrm{HIV} \% 22+\mathrm{O}$ R+\%22HIV\%2B\%22+or+\%22HIV-1\%22+OR+\%22HIV-2\%22+OR+ $\% 22 \mathrm{HIV} 1 \% 22+\mathrm{OR}+\% 22 \mathrm{HIV} 2 \% 22+\mathrm{OR}+\% 22 \mathrm{HIVAIDS} \% 22+\mathrm{OR}+\%$ $28 \% 22$ human+immun $\% 22+N E A R \% 2 F 2+\% 22$ virus $\% 22 \% 29+O R$ +\%22human+immunodeficiency+virus\%22+OR+\%22human+im munodeficiency+virus+infection $\% 22 \% 29+$ AND+\%28\%22screeni ng $\% 22+O R+\% 22$ test $\% 22+O R+\% 22$ retest $* \% 22+O R+\% 22$ rescre en*\%22+OR+\%22re-test*\%22+OR+\%22re-screen*\%22\%29+

\section{ClinicalTrials.gov}

Advanced search:

Conditions: "HIV" OR "HIV+" or "HIV-1" OR "HIV-2" OR "HIV1" OR "HIV2" OR "HIVAIDS" OR "human immununodeficiency virus"

Interventions: "screening" OR "testing" OR "retesting" OR "rescreening" OR "re-testing" OR "re-screening"

Timeframe: Studies received on or after 01/01/2000

Results: 649 items returned

Link to results: Clinical Trials.gov (https://clinicaltrials.gov/ct2/ results/displayOpt?flds $=a \& f l d s=b \& f l d s=t \& s u b m i t \_f l d \_o p t=o n$ \&=Update+Display\&cond $=\% 22 \mathrm{HIV} \% 22+\mathrm{OR}+\% 22 \mathrm{HIV} \% 2 \mathrm{~B} \% 2$ $2+$ or $+\% 22 \mathrm{HIV}-1 \% 22+\mathrm{OR}+\% 22 \mathrm{HIV}-2 \% 22+\mathrm{OR}+\% 22 \mathrm{HIV} 1 \% 22$ +OR+\%22HIV2\%22+OR+\%22HIVAIDS\%22+OR+\%22human + immununodeficiency+virus $\% 22$ \&intr $=\% 22$ screening $\% 22+\mathrm{O}$ $\mathrm{R}+\% 22$ testing $\% 22+\mathrm{OR}+\% 22$ retesting $\% 22+\mathrm{OR}+\% 22$ rescreen ing $\% 22+\mathrm{OR}+\% 22$ re-testing $\% 22+\mathrm{OR}+\% 22$ re-screening $\% 22 \& \mathrm{r}$ cv_s=01\%2F01\%2F2000\&show_flds $=Y$ )

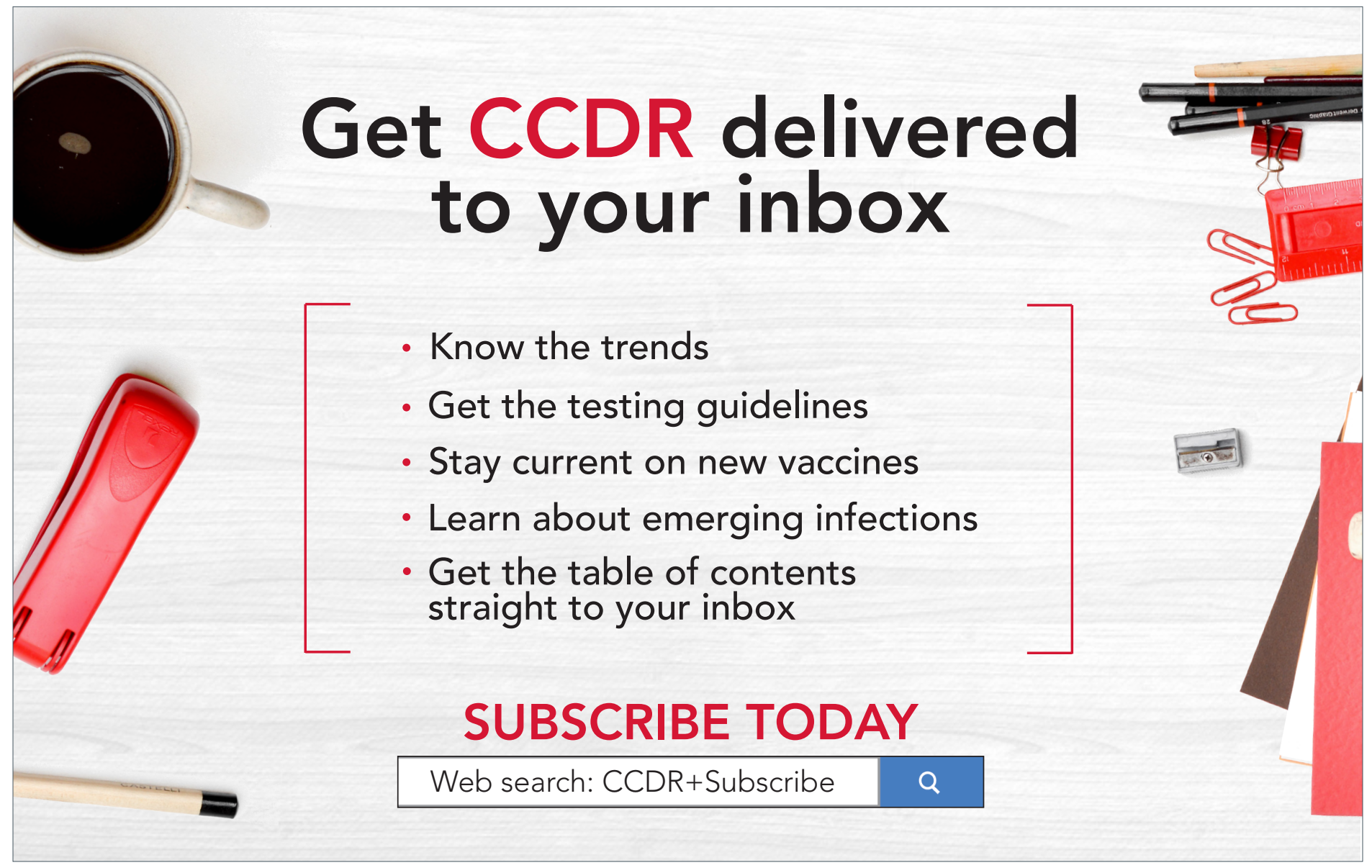

